Огляди літератури, оригінальні дослідження, погляд на проблему, випадок з практики, короткі повідомлення УДК 616-001:616.127-008.9:616.71-007.234]-092.4

DOI 10.11603/1811-2471.2020.v.i4.11763

\title{
ГІСТОФУНКЦІОНАЛЬНІ ЗМІНИ В ТКАНИНАХ НИРКИ В ДИНАМІЦІ ПОСТТРАВМАТИЧНОГО ПЕРІОДУ ПРИ ПОЄДНАНІЙ ТРАВМІ НА ТЛІ ГІПОКІНЕТИЧНОГО ОСТЕОПОРОЗУ В ЕКСПЕРЕМЕНТІ
}

\author{
○В. М. Лучинський ${ }^{1,}$ Г. В. Стойкевич ${ }^{1}$, Х. В. Погорецька ${ }^{1}$, Ю. В. Прокопчук ${ }^{2}$ \\ Тернопільський національний медичний університет імені І. Я. Горбачевського МОз України ${ }^{1}$ \\ Одеський національний медичний університет²
}

\begin{abstract}
РЕзюМЕ. Метою роботи є вивчення впливу політравми на структурні зміни в тканинах нирки у тварин з гіпокінетичним остеопорозом у динаміці посттравматичного періоду.

Матеріал і методи. Експерименти виконано на 42 нелінійних білих щурах-самцях масою 200-220 г. У першій серії експериментів у тварин викликали гіпокінетичний остеопороз за методом Z. Kundurovich, через 2 місяці моделювали політравму. У другій серії аналогічні травми наносили тваринам без остеопорозу. Тварин виводили 3 експерименту на 10, 20 та 30-ту доби. Для гістологічного дослідження забирали тканини нирки, їх структуру вивчали у нормі, а також характер і глибину морфологічних змін після модельованої політравми.

Результати. Дослідження показали, що на 10-ту добу експерименту у тварин без остеопорозу та у тварин 3 остеопорозом зміни в нирках були відносно однаковими: в нирках мало місце повнокров' я судин інтерстиціальної тканини переважно венозного типу та повнокров'я клубочків. Спостерігалась також білкова дистрофія епітелію дистальних та проксимальних відділів канальців. На 20-ту добу в нирковій тканині тварин з остеопорозом були слабо виражені дистрофічні зміни. У тварин з гіпокінетичним остеопорозом на 30-ту добу в нирках розвиваються повнокров'я клубочків та судин інтерстиціальної тканини кіркового шару, виражена білкова дистрофія епітелію дистальних та проксимальних відділів канальців.

Висновки. Наведені гістологічні відхилення в нирках в цілому підтверджують розвиток системних порушень при TX, які у тварин без остеопорозу наростають до 20-ї доби і до 30-ї стихають. У випадку одночасного гіпокінетичного остеопорозу гістологічні відхилення $є$ більш тривалими.

КлючовІ СлОВА: політравма; гіпокінетичний остеопороз; нирки; гіподинамія.
\end{abstract}

Вступ. Обмеження рухливості, що обумовлюється способом життя, особливостями професійної діяльності, довготривалим перебуванням у ліжку в період захворювання, викликає стан гіпокінезії та, в ряді випадків, супроводжується дефіцитом м'язового навантаження (гіподинамія) [4]. Цей стан призводить до зменшення навантаження на органи та системи, розвитку гіпокінетичного остеопорозу. Гіпокінезія стимулює розвиток дисбалансу в діяльності нирок. Спостерігаються суттєві порушення водно-електролітного обміну, які при короткочасному обмеженні рухової активності зумовлені перерозподілом рідких середовищ організму, а при тривалій гіпокінезії - змінами тканинного метаболізму. Перебудова функціонування нирок $\epsilon$ також наслідком зміни їхньої осмо- та іонорегулювальної функцій, негативного балансу електролітів, що, у свою чергу, може викликати сечокам'яну хворобу [6, 7]. В сучасному світі особливої актуальності набула проблема надання допомоги постраждалим із поєднаною травмою, оскільки саме наслідки тяжкої механічної травми $\epsilon$ головною причиною смертності осіб молодого працездатного віку $[1,3,5]$.

Численні дослідження довели, що тяжка поєднана травма значно впливає на роботу всіх внутрішніх органів та систем. Проте в доступній літературі не повною мірою висвітлено зміни в нирках після поєднаної травми в динаміці посттравматичного періоду на фоні гіпокінетичного остеопорозу.

Мета - вивчити вплив політравми на структурні зміни в тканинах нирки в динаміці посттравматичного періоду в тварин з гіпокінетичним остеопорозом.

Матеріал і методи дослідження. Експерименти виконано на 42 нелінійних білих щурахсамцях масою 200-220 г. У першій серії експериментів у тварин викликали гіпокінетичний остеопороз за методом Z. Kundurovich (1989) шляхом накладання на тіло тварини гіпсового корсета, що суттєво знизило їх рухову активність [8]. Через 2 місяці корсет знімали й у тварин моделювали політравму спеціально розробленим способом шляхом пошкодження двох кісткових сегментів: стегна і нижньої щелепи [2].

У другій серії аналогічно травмували тварин без остеопорозу. Контрольну групу склали інтактні тварини. Нанесення травм здійснювали в умовах тіопентало-натрієвого знеболювання (40•мг•Кг $\left.{ }^{1}\right)$.

Тварин виводили з експерименту на 10, 20 та 30-ту доби в умовах тіопентало-натрієвого знеболювання. Для гістологічного дослідження забирали тканини міокарда, які фіксували в 10 \% нейтральному розчині формаліну з наступним ущільненням у парафіні. Отримані на санному мікротомі зрізи фарбували гематоксиліном та еозином, за 
Огляди літератури, оригінальні дослідження, погляд на проблему, випадок з практики, короткі повідомлення ними вивчали структуру досліджуваних тканин у нормі, а також характер і глибину морфологічних змін після модельованої політравми. Використовували мікроскоп ЛОМО Биолам И та систему цифрового виведення зображень гістологічних препаратів. При вивченні морфологічної організації досліджуваних органів звертали увагу на зміни паренхіми і основних структурних компонентів.

Результати й обговорення. На 10-ту добу посттравматичного періоду в тварин без гіпокінетичного остеопорозу та у тварин із модельованим гіпокінетичним остеопорозом структурні зміни в нирках проявлялися однаково: розладами кровообігу, які були представлені нерівномірним кровонаповненням капілярів клубочків та судин строми кіркового та мозкового шарів, стазом, сладж-феноменом. Проте, якщо в стромі переважало повнокров'я, то більшість клубочків мали знижене кровонаповнення або були ішемізованими. Суттєві зміни виявлялися в епітелії проксимальних та дистальних відділів канальців. Епітелій виглядав набряклим, місцями спостерігалася апікальна його десквамація. Цитоплазма частини клітин була зернистою, в інших - вакуолізованою. Ядра мали різні розміри: від пікнотичних гіперхромних до набухлих та гіпсохромних (рис. 1).

Морфологічні зміни на 20-ту добу посттравматичного періоду в тварин без гіпокінетичного остеопорозу проявлялись змінами в кірковому шарі нирки. Клубочки були дещо розширеними, в їх просвітах спостерігалась незначна кількість серозного ексудату. Судини венозного русла дещо розширювались, були повнокровними, візуалізувались дрібні периваскулярні точкові крововиливи.

У тварин з гіпокінетичним остеопорозом на 20-ту добу при гістологічному дослідженні тканини нирки ми спостерігали, що у кірковому шарі

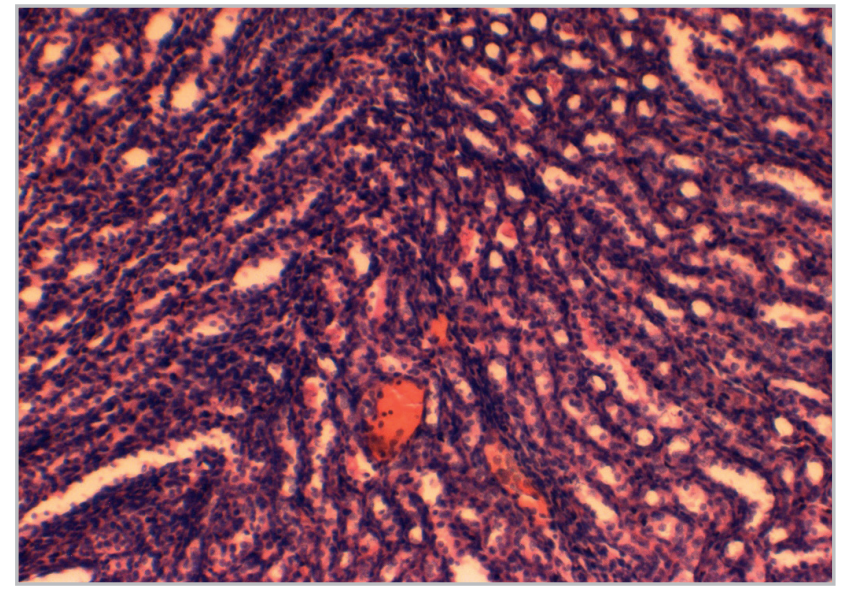

Рис. 1. Гістологічна структура тканини нирки тварини на 10-ту добу експерименту при моделюванні політравми на фоні остеопорозу. Забарвлення гематоксиліном та еозином. $\times 200$. нирки клубочки також були дещо розширеними, судини їх повнокровними, в просвітах спостерігався серозний та серозно-геморагічний ексудат, проте окремі клубочки були зморщеними, колабованими.

Судини венозного русла дещо розширювались, були повнокровними, візуалізувались дрібні периваскулярні точкові крововиливи. Переважна більшість вивідних канальців були розширеними, проте просвіти їх були вільними від ексудату. В петлях Генле і прямих канальцях ми спостерігали виражений набряк епітелію.

У дистальних канальцях мали місце гіаліновокрапельна та гідропічна білкова дистрофія, еозинофілія цитоплазми, а також слабкий зв'язок пошкодженого епітелію із базальною мембраною. Велика кількість епітеліоцитів не містили ядер, що свідчить про наявність дистрофічно-некротичних змін. В судинах мозкового шару також спостерігалися повнокров'я та периваскулярний набряк, який поєднувався із незначною периварискулярною лімфогістіоцитарною інфільтрацією.

На 30 добу посттравматичного періоду у тварин без остеопорозу в кірковому шарі нирки капсули клубочків дещо розширювались, в їх просвітах спостерігалась незначна кількість серозно-геморагічного ексудату. Судини венозного русла були дещо розширеними, повнокровними, візуалізувались дрібні периваскулярні точкові крововиливи.

У переважній більшості вивідних канальців просвіти були розширеними, проте не містили ексудату та клітинних елементів. У петлях Генле і прямих канальцях ми спостерігали помірний набряк епітелію.

У дистальних вивідних канальцях мали місце слабовиражена білкова дистрофія та еозинофілія цитоплазми (рис. 2). В судинах мозкового шару

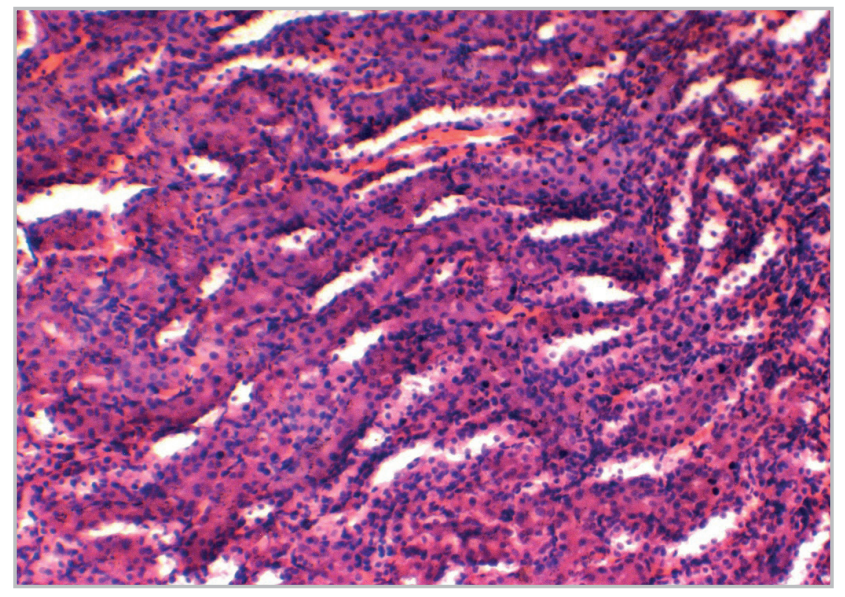

Рис. 2. Гістологічна структура тканини нирки тварини на 30-ту добу експерименту при моделюванні політравми (на фоні остеопорозу). Забарвлення гематоксиліном та еозином. $\times 200$ 
Огляди літератури, оригінальні дослідження, погляд на проблему, випадок з практики, короткі повідомлення також спостерігали повнокров'я та периваскулярний набряк, який поєднувався із незначною периваскулярною лімфогістіоцитарною інфільтрацією.

У тварин з гіпокінетичним остеопорозом спостерігали такі ж самі зміни, але, крім того, ми відзначали, що в епітелії дистальних канальців спостерігалися помірна білкова дистрофія, еозинофілія цитоплазми а також місцями слабкий зв'язок пошкодженого епітелію із базальною мембраною (рис. 2).

Висновки. Політравма супроводжується гістологічними відхиленнями в нирках, які більш ви-

ражені у тварин з гіпокінетичним остеопорозом у всі терміни спостереження, проте на 30 добу в нирках розвиваються повнокров'я клубочків та судин інтерстиціальної тканини кіркового шару, виражена білкова дистрофія епітелію дистальних та проксимальних відділів канальців.

Перспективи подальших наукових досліджень. У перспективі доцільно розробити методичні підходи до корекції виявлених порушень у нирках, як в умовах самої політравми, так і за її поєднання з гіпокінетичним остеопорозом.

\section{ЛІТЕРАТУРА}

1. Агаджаниян В. В. Госпитальная летальность при политравме и основные направления ее снижения / В. В. Агаджаниян, С. А. Кравцов, Шаталин А. В. // Политравма. - 2015. - № 1. - С. 6-15.

2. Пат. України № u 2012 13431. Спосіб моделювання політравми / А. А Гудима, Г.В.Федірко ; заявник і патентовласник Терноп. держ. мед. ун-т імені І. Я. Горбачевського. опубл. 26 лист. 2012.

3. Иноземцев Е. О. Актуальные вопросы хирургии сочетанных повреждений (по материалам публикаций журнала «Травма») / Е. О. Иноземцев, Е. Г. Грегорьев, К. А. Апарцин // Политравма. - 2017. - № 1. - С. 6-11.

4. Качелаева Л. К. Гиподинамия и здоровье человека / Л. К. Качелаева, Р. Р. Тахаутдинов // В мире научных открытий. - 2010. - № 4 (10 4. 4). - С. 26-27.

\section{REFERENCES}

1. Agadzhaniyan, V.V., Kravtsov, S.A., \& Shatalin, A.V. (2015). Gospitalnaya letalnost pri politravme i osnovnyye napravleniya yeye snizheniya [Hospital lethality with polytrauma and the main directions of its decrease]. PolitravmaPolytrauma, 1, 6-16 [in Russian].

2. (2012). Hudyma, A.A, Fedirko, H.V. Pat. Ukrainy Sposib modeliuvannia politravmy [Method for modeling polytrauma]; zaiavnyk i patentovlasnyk Ternop. derzh. med. un-t imeni I. Horbachevskoho. № u 2012 13431. opubl. 26 lyst. 2012 [in Ukrainian].

3. Inozemtsev, Ye.O., Gregoryev, Ye.G., \& Apartsin, K.A. (2017). Aktualnyye voprosy khirurgii sochetannykh povrezhdeniy (po materialam publikatsiy zhurnala "Travma») [Topical issues ofsurgery of combined injuries (based on the publications of the journal "Trauma"]. Politravma - Polytrauma, 1, 6-11 [in Ukrainian].

4. Kachelayeva, L.K., \& Takhautdinov, R.R. (2010). Gipodinamiya i zdorovye cheloveka [Hypodynamia and human health]. $V$ mire nauchnykh otrkrytiy - In the World of Scientific Discoveries, 4 (10 Ch 4), 26-27 [in Russian].

5. Козопас В. С. Травма таза при політравмі: догоспітальний етап надання допомоги / В. С. Козопас // Травма. - 2014. - № 15 (1). - С. 96-99.

6. Слинько Ю. О. Недостатня рухова активність та її вплив на стан організму / Ю.О.Слинько // Медицина сьогодні і завтра. - 2014. - № 2-3. - С. 63-64.

7. Смирнов А. В. Гиподинамия и гипокинезия факторы риска для лиц с ограниченными возможностями и отклонениями в состоянии здоровья : материалы XVIII Всероссийской науч.-практ. конф. - Томск, 2015. C. $122-124$.

8. Kundurovich $Z$. The effects of gypcin cuff streess provocation on the level of $\mathrm{Ca}$ and the body weight in rats / Z. Kundurovich, M. Hynjicevich, A. Causevich // Arch. Biol. Yugosl. - 1989. - Vol. 27 (7). - P. 79-80.

5. Kozopas, V.S. (2014). Travma taza pry politravmi: dohospitalnyi etap nadannia dopomohy [Trauma of the pelvis under polytrauma: pre-hospital stage of rendering of help]. Travma - Trauma, 15 (1), 96-99 [in Ukrainian].

6. Slynko, Yu.O. (2014). Nedostatnia rukhova aktyvnist ta yii vplyv na stan orhanizmu [Insufficient motor activity and its impact on the body]. Medytsyna sohodni i zavtra Medicine Today and Tomorrow, 2-3, 63-64 [in Ukrainian].

7. Smirnov, A.V. (2015). Gipodinamiya i gipokineziya faktory riska dlya lits s ogranichennymi vozmozhnostyami i otkloneniyami v sostoyanii zdorovya [Hypodinemia and hypokinesia are risk factors for persons with disabilities and abnormalities in health status]. Materialy XVIII Vserossiyskoy nauchno-prakticheskoy konferentsii "Aktualnyye voprosy fizicheskoy kultury i sporta» - Materials of the XVIII AllRussian Scientific and Practical Conference "Actual Issues of Physical Culture and Sports. Tomsk [in Russian].

8. Kundurovich, Z. (1989). The effects of gypcin cuff streess provocation on the level of $C a$ and the body weight in rats. Arch. Biol. Yugosl., 27 (7), 79-80. 
Огляди літератури, оригінальні дослідження, погляд на проблему, випадок з практики, короткі повідомлення

ГИСТОФУНКЦИОНАЛЬНЫЕ ИЗМЕНЕНИЯ В ТКАНЯХ ПОЧКИ В ДИНАМИКЕ

ПОСТТРАВМАТИЧЕСКОГО ПЕРИОДА ПРИ СОЧЕТАННОЙ ТРАВМЕ НА ФОНЕ ГИПОКИНЕТИЧЕСКОГО ОСТЕОПОРОЗА В ЭКСПЕРИМЕНТЕ

\author{
○В. М. Лучинский ${ }^{1}$, Г. В. Стойкевич ${ }^{1}$, К. В. Погорецкая ${ }^{1}$, Ю. В. Прокопчук ${ }^{2}$
}

Тернопольский национальный медицинский университет имени И. Я. Горбачевского МОз Украины ${ }^{1}$

Одесский национальный медицинский университет²

РЕЗЮМЕ. Целью работы стало изучение влияния политравмы на структурные изменения в тканях почки у животных с гипокинетическим остеопорозом в динамике посттравматического периода.

Материал и методы. Эксперименты выполнены на 42 нелинейных белых крысах-самцах массой 200-220 г. В первой серии экспериментов у животных вызывали гипокинетический остеопороз методом Z. Kundurovich, через 2 месяца моделировали политравму. Во второй серии аналогично травмировали животных без остеопороза. Животных выводили из эксперимента на 10, 20 и 30-е сутки. Для гистологического исследования забирали ткани почки, их структуру изучали в норме, а также характер и глубину морфологических изменений после моделируемой политравмы.

Результаты. Исследования показали, что на 10-е сутки эксперимента у животных без остеопороза и у животных с остеопорозом изменения в почках были схожими: в почках имели место полнокровие сосудов интерстициальной ткани преимущественно венозного типа и полнокровие клубочков. Наблюдалась также белковая дистрофия эпителия дистальных и проксимальных отделов канальцев. На 20-е сутки в почечной ткани животных с остеопорозом имели место слабо выраженные дистрофические изменения. У животных с гипокинетическим остеопророзом на 30-е сутки в почках развиваются полнокровие клубочков и сосудов интерстициальной ткани коркового слоя, выраженная белковая дистрофия эпителия дистальных и проксимальных отделов канальцев.

Выводы. Приведенные гистологические отклонения в почках в целом подтверждают развитие системных нарушений при TX, которые у животных без остеопороза нарастают до 20-го дня и до 30-го стихают. В случае одновременного гипокинетического остеопороза гистологические отклонения более продолжительные.

КЛЮчЕВЫЕ СЛОВА: политравма; гипокинетический остеопороз; почки; гиподинамия.

\title{
HISTOFUNCTIONAL CHANGES IN KIDNEY TISSUES IN DYNAMICS OF POST-TRUMATIC PERIOD IN POLYTRAUMA ASSOCIATED WITH HYPOKINETIC OSTEOPOROSIS IN THE EXPERIMENT
}

\author{
๑V. M. Luchynskyi', H. V. Stoikevych'1, K. V. Pohoretska', Yu. V. Prokopchuk ${ }^{2}$ \\ I. Horbachevsky Ternopil National Medical University \\ ${ }^{3}$ Odesa National Medical University ${ }^{2}$
}

SUMMARY. The aim - to study the effect of polytrauma on structural changes in kidney tissues in the post-traumatic period in animals with hypokinetic osteoporosis.

Material and Methods. Experiments were performed on 42 non-linear white male rats weighing 200-220 g. In the first series of experiments in animals, hypokinetic osteoporosis was induced by the method of Z. Kundurovich, after 2 months of modeling a polytrauma. In the second series, animals without osteoporosis were similarly injured. Animals were extracted from the experiment for 10, 20 and 30 days. For histological examination, the tissues of the kidney were removed, their structure was studied normally, as well as the nature and depth of morphological changes after the simulated polytrauma.

Results and Discussion. Studies showed that on day 10 of the experiment in animals without osteoporosis and in animals with osteoporosis, changes in the kidneys were relatively the same: in the kidneys there was a plethora of vessels of inertial tissue, mainly of the venous type, and plethora of glomeruli. There was observed protein dystrophy of the epithelium in the distal and proximal tubules. Weak dystrophic changes were on day 20 day in the renal tissue of animals with osteoporosis. On 30 day in animals with hypokinetic osteoprorosis in the kidneys develops plethora of glomeruli and vessels of the interstitial tissue of the cortical layer, protein dystrophy of the epithelium of the distal and proximal tubules.

Conclusions. These histological abnormalities in the kidneys in general confirm the development of systemic disorders in traumatic disease, which in animals without osteoporosis increase by the 20th day and subside by the 30 th. In the case of concomitant hypokinetic osteoporosis, histological abnormalities are longer.

KEY WORDS: polytrauma; hypokinetic osteoporosis; kidney; hypodynamics. 